\title{
The Rise of Neoliberalism and the Termination of Keynesian Policies: A Multilevel Governance Analysis of the Closure of the Amsterdam Shipyards, 1968-1986
}

\author{
SJOERD KEULEN \\ RONALD KROEZE
}

By looking at the policy termination of state aid to shipbuilders in Amsterdam, this article illustrates how a major policy paradigm shift within recent history, and the change from Keynesian to neoliberal policies, can be explained. The article is informed by a multilevel governance approach to policy change analysis and is based on different types of sources. It presents an in-depth case study of the closing of the Amsterdam shipyards and analyzes the role of policy change at different governance levels (i.e., city government, national Parliament, national government, and the European Commission). In doing so, we are able to illustrate how new actors-in this case the European Commission and the Commissioner for Competition-were able to terminate long-existing policies of state aid to shipbuilders under the auspices of improving competition and the free market at the start of the 1980 s.

(c) The Author 2020. This is an Open Access article, distributed under the terms of the Creative Commons Attribution licence (http://creativecommons.org/ licenses/by/4.0/), which permits unrestricted re-use, distribution, and reproduction in any medium, provided the original work is properly cited.

doi:10.1017/eso.2019.65

Published online March 16, 2020

SJOERD KEULEN is auditor at the Netherlands Court of Audit and assistant professor of Public Administration at Erasmus University Rotterdam. His research areas are (the history of) accountability, budget policy, and financial management, as well as business history and management history. Contact information: Erasmus University, Department of Public Administration and Sociology, Mandeville Building T17-20, P.O. Box 1738, 3000 DR Rotterdam, Netherlands. E-mail: keulen@essb.eur.nl

Ronald KROEZE is associate professor of History at Vrije Universiteit Amsterdam. His research areas are the history of governance, democracy and (anti-)corruption, as well as business history, management history, and oral history. Contact information: Faculty of Humanities, Art and Culture, History, Antiquity, Vrije Universiteit Amsterdam, De Boelelaan 1105, 1081 HV Amsterdam, Netherlands. E-mail: d.b.r.kroeze@vu.nl 


\section{Introduction}

Shipbuilding was one of the pillars of the Dutch economy after World War II. In 1970, about 5 percent of the total labor force worked in shipbuilding, more than in any other Western European country. ${ }^{1}$ The large yards were concentrated in the two largest harbors of the Netherlands: Rotterdam and Amsterdam. To be able to compete with Japan, the Netherlands followed the European policy of centralization of activities. Concrete examples are the series of mergers of the main Amsterdam shipyards into an ever-expanding conglomerate. Eventually, Rijn-Schelde-Verolme (RSV) was established in 1971: This conglomerate combined 117 individual companies and employed 20,000 workers, of whom an estimated quarter worked in the Amsterdam dockyards. In the years following the merger, the government, in close cooperation with the trade unions and the management of RSV, initiated the restructuring of the shipyards to make them more efficient and competitive. This policy contributed to an increasing divide between north and south, in which the cities of Amsterdam (north, Amsterdam Drydock Corporation [ADM] and Netherlands Dockyard and Shipbuilding Corporation [NDSM]) and Rotterdam (south, shipyards such as Verolme, Wilton-Feijenoord, and Rotterdamsche Droogdok Maatschappij RDM), supported by the local unions and workers, tried to prevent their yards from being closed. ${ }^{2}$ Moreover, this policy was costly. Over the years, the national government supported the RSV with 2.7 billion guilders (worth $€ 2.25$ billion in 2018).

Shipbuilding had a major impact on urban policy making. Looking at Amsterdam, the development of the harbor clearly had been the main focus of economic development initiatives in the city to provide jobs and economic growth after World War II. The two main RSV company shipyards (NDSM and ADM) were located in the north of Amsterdam, a working-class area with traditionally high levels of unemployment. ${ }^{3}$ The city government actively lobbied for government support in The Hague after the RSV conglomerate was hit by the effects of the first oil crisis of 1973 and encountered stiff competition from Southeast Asian shipbuilders from the 1970s onward.

Parliament was another actor. In the 1970s, Parliament was strongly opposed to closing shipyards, in order to bolster employment, even if the shipyards were losing money. In 1983, the RSV conglomerate suddenly went bankrupt. Parliament was in shock and initiated a parliamentary inquiry into the causes of this failure. The parliamentary

\footnotetext{
1. Strath, The Politics of De-industrialization, 155.

2. Strath, The Politics of De-industrialization, 155-163.

3. Bosscher, "De oude en de nieuwe stad."
} 
inquiry (itself a media event, as it was the first inquiry to be broadcast on television), contributed to a major shift in economic policy: from Keynesian state-supported industrialization with the aim of protecting jobs to a neoliberal policy with a focus on cost-cutting, competition, and efficiency. Although the Amsterdam city government protested, it could not prevent this shift.

To fully understand this policy paradigm shift, one must also consider the changing role of and pressure from the European Community. Particularly from 1980 onward, a series of European Commission (EC) directives had urged curtailing state aid to shipbuilders; these acts were supported by rulings of the European Court that contained the first fines for illicit state aid. As a result of these pressures from different governance levels, the RSV conglomerate was split up between 1983 and 1986. In the long run, only a few former RSV activities would survive.

This article focuses on the decline of shipyards in the city of Amsterdam to understand how a policy paradigm shift from Keynesian to neoliberal policies occurred in recent history. By Keynesian policy we mean policies inspired by the assumption that that the government has to guarantee (full) employment by stimulating economic growth through government spending (demand management). The assumption of this management of aggregated demand economics is that government spending will lead to proportionally higher economic growth (the multiplier effect). Moreover, the state should guide the national economy primarily through a permanent program of large-scale public investments. Just as important for Keynes was the microeconomic aspect of unregulated competition, which-especially during times of economic crisis-leads to unemployment, excess capacity, and suffering. He believed that the state should therefore act by introducing "regulated competition" ${ }^{4}$ in which, in the words of Nobel laureate economist Edmund Phelps, "the government [had] to assist the ongoing movement towards cartels, holding companies, trade associations, pools and others forms of monopoly power." ${ }^{5}$ The limits of this approach became apparent in the 1970s when stagflation occurred: a situation of inflation (partly) caused by increasing government spending and rising unemployment. This situation could not happen according to Keynesian economics. As a result, policy makers started to look for new solutions. ${ }^{6}$ This gave neoliberalism a chance. Neoliberalism

4. Crotty, "Was Keynes a Corporatist?"

5. Phelps, "Corporatism and Keynes," 93.

6. Jones, Masters of the Universe, 215 et passim; Tomlinson, Managing the Economy, 63-87. 
had its roots in the 1930s and consisted of different schools. ${ }^{7}$ The most vocal school of neoliberalism that gained influence in the 1970s is the Chicago School of economists such as Milton Friedman. His neoliberal politics or neoliberalism can be defined as a combination of a more restrictive role for the state, as well as a reappraisal of free trade and a greater role for market forces (competition). ${ }^{8}$ An important element of this type of neoliberalism is the economic philosophy of monetarism, which does not focus on the demand side or on government spending, but rather on the supply of money to stimulate growth. From a monetarist perspective, inflation is not a sign of government underspending but of government overspending, which should be countered by terminating state subsidies and privatization of state assets. ${ }^{9}$

Although many would agree that this is a period of crucial changes in recent history, there are still few historical in-depth case studies of this policy change. And some crucial players, such as the EC, are often not included in analyses of shifts in Dutch economic policy. ${ }^{10}$ The duration of the closure of the Amsterdam shipyards-it took almost two decades-and the availability of sources on the role of different actors makes this a case in point to highlight how the Keynesian economic policy approach was replaced by a new neoliberal economic policy approach, backed by the EC. In addition, this is a study into how policies are terminated: After the RSV scandal, the protection of employment in vulnerable (urban) regions ceased to be a major determinant in decisions surrounding economic aid to industry. Finally, as mentioned earlier, the role of different governance levels is analyzed to understand this shift. Therefore, the article contributes to the use of the multilevel governance approach in history, which is also an underutilized perspective in history. ${ }^{11}$

In the first section, we explain why it is insightful to understand this transformation as a policy paradigm shift. Moreover, we also introduce here the multilevel governance approach in relation to the theme of how policies are terminated. In the second section, the two shipyards of Amsterdam and their merger into the RSV conglomerate in 1971 are further discussed. The third section shows how the Amsterdam case reflects the European model of concentration and subsidies in shipbuilding in the 1970s. The fourth section tells the story of the changing European state aid policy. The fifth section shows the struggle of the

7. Plehwe, "Introduction."

8. Warlouzet, Governing Europe; Hall, "Policy Paradigms," 284; Stone, Goodbye to All That?, 180, 181.

9. Ther, Europe Since 1989; Burgin, The Great Persuasion.

10. See, e.g., Van Zanden, "The History of an Empty Box."

11. Stephenson, "Twenty Years of Multi-level Governance”; Van Meurs, Never Mind the Gap. 
city of Amsterdam to find support for its dockyards in the 1980s, and how first the EC and then the national Parliament were reluctant to provide it. Finally, the sixth section discusses parallels with developments in the United Kingdom, France, and Germany.

\section{Policy Termination and Multilevel Governance}

One of the aims of this article is to explain how policies are terminated and replaced by others. Policy termination became a subject of study in the late 1970s. It was the last step of the then influential policy cycle method. In this model, termination would be the logical end for unsuccessful policies. However, in practice, termination could hardly be observed. ${ }^{12}$ Policy termination is defined as "the deliberate conclusion or cessation of specific government functions, programs, policies, or organizations." ${ }^{\prime 13}$ In the early 1980s, an academic consensus emerged that there were three criteria for policy termination: financial reasons (budget cuts), governmental (in)efficiencies, and changing political ideologies. DeLeon emphasized that "although perhaps the most difficult to defend and to define of the three termination criteria, political ideology has increasingly been forwarded as the basic cause or motivating factor in program terminations and budget reductions." ${ }^{14}$ By the mid-1990s, ideological reasons were named as the most decisive for policy termination. ${ }^{15}$ Geva-May, inspired by Kingdon's theory on policy windows, explained that policy proposals “may require years of 'softening up' but that shifts of ideology, national mood, or crisis-political, economic, or legislative shifts and changes of personnel—can bring issues up on the public agenda and prompt window openings." 16

To better understand major changes in ideology, we have to turn to the research on policy paradigm shifts. The notion of policy paradigms was popularized by the political scientist Peter Hall, an exponent of historic institutionalism in policy sciences in the years around 1990. Hall's concept of policy paradigms was based on Thomas Kuhn's concept of "paradigm shifts." Kuhn argued that scientific revolutions are not the result of linear developments but that they are sudden ruptures, which should be partly understood as the result of new insights and partly as a result of a new consensus in a scientific community about

12. Bardach, "Policy Termination as a Political Process"; DeLeon, "Public Policy Termination."

13. Brewer and DeLeon, The Foundations of Policy Analysis, cited in Daniels, "Policy and Organizational Termination," 250.

14. DeLeon, "Policy Evaluation and Program Termination," 636.

15. Harris, "Policy Termination."

16. Geva-May, "Riding the Wave of Opportunity," 320. Emphasis in original. 
what is scientific truth. Although other paradigms do exist, the new consensus favors one paradigm over others, resulting in alternative paradigms not being seen as valid at the same time. ${ }^{17}$ Informed by Kuhn (and also by Heclo's notions on social learning by civil servants), ${ }^{18}$ Hall argues that establishing consensus on what is the best public policy takes place in the context of a wider, changing discursive framework. How policy is debated and understood determines the "very nature of the problems ... Like a Gestalt, this framework is embedded in the very terminology through which policymakers communicate about their work, and it is influential precisely because so much of it is taken for granted and unamenable to scrutiny as a whole. I am going to call this interpretive framework a policy paradigm.” By using the notion of policy paradigm, Hall has explained Britain's radical shift from Keynesian to neoliberal policies between 1970 and 1989. During this policy paradigm shift, all three components of policy changed: "the instruments' setting, the instruments themselves, and the hierarchy of the goals behind the policy."19

Since Hall's work, the approach to understanding paradigm shifts has been further developed. An influential group of scholars has argued that long periods of stability and policy continuity are being disrupted by short and intense periods of change. Existing policy paradigms are socially constructed and dominant in a given policy system; they tend to reinforce themselves and are static. During a policy paradigm shift, it is likely that a dominant policy community is being replaced or that new political actors intervene. ${ }^{20}$ The growing dominance of the EC in the 1980s toward the formation of a single market in 1992 means that the EC could be considered a player initiating a paradigm shift, as we will further discuss later. ${ }^{21} \mathrm{~A}$ second group of scholars has argued that paradigm shifts are much more gradual and incremental and some aspects of former policies remain in place, while others are changed. ${ }^{22}$ An example of the second group is the work of political scientists Princen and Van Esch on changing policy paradigms in subsequent versions of the Stability Growth Pact of the European Monetary Union. They found that changes were gradual and that differing paradigms could even be present in a policy "without undermining the internal consistency of the argument." ${ }^{23}$ The problem with the gradual and incremental policy paradigm is that it is difficult to see the difference

17. Kuhn, The Structure of Scientific Revolutions.

18. Wilder, "What Is a Policy Paradigm?"

19. Hall, "Policy Paradigms," 279.

20. Baumgartner, Jones, and Mortensen, "Punctuated Equilibrium Theory."

21. E.g., Ludlow, "Jacques Delors."

22. E.g., Mahoneyand and Thelen, Explaining Institutional Change.

23. Princen and Van Esch, "Paradigm Formation and Paradigm Change," 372. 
between policy theories and paradigms, and that it goes beyond the fact that policy paradigms, because of their Kuhnian origins, should be rare and should lead to a radical if not revolutionary process. ${ }^{24}$ It is suggested that one should see policy theories as "operationalization" of policy paradigms, that the impact of an paradigm change runs through change in policy theories. ${ }^{25}$ Scholars of policy termination have argued that the "explosion-type ending" is the most common form-it is likely that the paradigm shift will be disruptive and therefore easy to identify because of the stark contrast produced by this kind of ending. ${ }^{26}$ In sum, the concept of paradigm shifts is useful for historians, because it enhances our understanding of how a radical change in discourse has a performative effect on politics and policy: It changes the substance of policy-in our case in the form of a termination. ${ }^{27}$

The concept of paradigm shifts also makes us sensitive to the fact that often new actors are responsible for a radical policy change. For our case, the sources confirm that different governance levels were involved in this process of change: the city of Amsterdam, the national Parliament, the government, and the European Community were the main actors. Trade unions and the management of shipyards also played a role, but to a lesser degree, as we will see. Because of the roles of different actors, the multilevel governance approach also informs research on policy paradigm shift. This approach has tried to offer a non-state and noncentric view on politics and policy to explain the transfer of (some) power from the nation-states and central governments in Europe to the supranational institutions of the European Community in the 1980s. ${ }^{28}$ Marks has emphasized the importance of ideas to understand changes taking place in three dimensions: political mobilization, that is, as the actors' attempt to influence the existing distribution of power and ideas (politics); policy-making arrangements (policy); and state structures (polity). ${ }^{29}$ Political scientists Marks, Hooghe, and Blank argued that although "Brussels" became more important, nationally elected politicians continued to be influential as well. ${ }^{30}$ In the last decade, multilevel governance studies have also included the urban level. ${ }^{31}$ Cities are especially viewed now as "an

24. Daigneault, "Reassessing the Concept of Policy Paradigm."

25. Princen and 't Hart, "Putting Policy Paradigms in Their Place."

26. Bardach, "Policy Termination as a Political Process," 125.

27. For historical representation, this intertwining of style and substance is explained in Ankersmit, Historical Representation. For its occurrence in politics, see Ankersmit, Aesthetic Politics.

28. Hooghe and Marks, Multi-level Governance, 28.

29. Piattoni, "Multi-level Governance."

30. Marks, Hooghe, and Blank, "European Integration from the 1980s," 342.

31. Gustavsson, Elander, and Lundmark, "Multilevel Governance." 
essential political mechanism through which a profound and geographical transformation of national states has been occurring," while city regions have become institutional players to which policy-making powers have been transferred from the national state level. ${ }^{32}$ Hence, this makes us sensitive to the role of Amsterdam in this case. So, by now we know that a clear hierarchy between different government levels is no longer fixed and in-depth case studies are required to find out their precise roles.

In short, by combining the concept of policy paradigm shifts with the multilevel governance approach, we hypothesize that the termination of policies is the result of a policy paradigm shift, itself the result of actions at different governance levels. To be able to establish that a paradigm shift took place, it is not necessary that the new paradigm is embraced by everyone. Or, as Kuhn explains: “To be accepted as a paradigm, a theory must seem better than its competitors, but it need not, and in fact never does, explain all the facts it can be confronted with." Those who remain followers of the old views "are simply read out of the profession, which thereafter ignores their work." ${ }^{33}$ Informed by these considerations, in the following sections we will analyze if, and if so, how and in what form, a paradigm shift took place in historical reality.

\section{Forced National Mergers to Acquire Subsidies}

The Amsterdam harbor had been the main focus of the economic development programs of the city in order to provide jobs and economic growth after World War II. The two main shipyards in AmsterdamNDSM and ADM - were located in the north of Amsterdam, a workingclass area with high levels of unemployment. In the 1960s, the two dockyards started to be locked in at their location, as the maximum depth and width of their ships were dictated by a sea lock and the canal to Amsterdam's harbor. ${ }^{34}$ The NDSM had approximately 3,500 workers at the end of the 1960s, while 1,500 workers were employed by the ADM dockyards. NDSM was one of the seven large shipbuilding companies in the Netherlands, nicknamed the "Seven Sisters." NDSM and ADM were responsible for 9 percent of the total employment in the Dutch shipbuilding and ship repair sector, which consisted of 252 (mainly small) companies in total in $1967 .^{35}$

32. Brenner, New State Spaces.

33. Kuhn, The Structure of Scientific Revolutions, 17-19.

34. Bosscher, "De oude en de nieuwe stad," 351.

35. Figures from Van der Velden, "The Dutch Shipbuilding Industry; Strath, The Politics of De-industrialization, 157. 
After World War II, to promote the reconstruction of the economy based on industrialization, the Dutch government had introduced a policy of wage restraint. The economic boom of the 1950s and 1960s, which made trade unions ask for higher wages, eventually brought an end to this "guided wage policy" in the early 1960s. As a result, wages in the Netherlands-which had been amongst the lowest-now were among the highest in Europe, which had a great effect on laborintensive sectors such as shipbuilding. These sectors were also the first to see rising unemployment from 1967 onward..$^{36}$ In a period in which the image of the "crisis of the 1930s" was still fresh and alive, Parliament asked the government to form a committee to research the shipbuilding sector in the Netherlands, which it feared was starting to decline. Indeed, the Netherlands had dropped from being the third producer of ships globally in the 1930s to number fourteen in the 1960s. The Keyzer commission (named after its chairman M.J. Keyzer), consisting of bankers, dockyard owners and shipowners, unionists, and government representatives, first recommended the provision of subsidies, which had become commonplace in other European countries by 1966. Second, the Keyzer commission concluded that the industry was relying too heavily on craftsmanship and therefore had to industrialize by introducing new production methods and to specialize by focusing on specific ship types in order to catch up with foreign competitors. Building supertankers for oil transport was seen as especially profitable. "The report was a masterpiece of social and economic architecture, a monument to an epoch when there was a strong belief that society's difficulties could be mastered by rational and determined action," according to Bo Strath. Strath also shows that the findings of the Keyzer commission were similar to conclusions drawn in West Germany and in the United Kingdom (e.g., the Geddes Report). ${ }^{37}$

The Keyzer report was turned into policy. In 1968, the Rotterdambased shipbuilder Verolme was forced by the national government to buy and integrate the unprofitable NDSM shipyard into Verolme activities in order to secure government loans for a super dry dock of 400 meters. Both new builds and ship repairs had ceased to be profitable for NDSM; the only profitable builds were mammoth tankers. As these ships had grown larger than the width of the sea locks in the Amsterdam port, the director of NDSM (Piet Goedkoop) was convinced that his company would never be profitable again and that no Dutch

36. Van Zanden, The Economic History of the Netherlands, 81; Van Zanden, “The History of an Empty Box,” 184.

37. Strath, The Politics of De-industrialization, 158, 159. 
shipbuilder would be able to compete with the Japanese. ${ }^{38}$ However, the merger did continue.

Against this background, three years later the nationalized superconglomerate of shipyards named Rijn-Schelde-Verolme (RSV) was formed. Only one large national shipbuilder out of the Seven Sisters managed to retain its independence, namely the ADM. The ADM was able to maintain its autonomy for several years, but would become part of the RSV in 1978. The argument for the formation of the RSV was capacity reduction, but soon the conglomerate agreed that the future of the struggling dockyards of Amsterdam had to be "to sustain employment as much as possible, while finding the most neutral solution in terms of distortion of competition." ${ }^{39}$ The Amsterdam shipyards of the conglomerate were forced to absorb the losses of the NDSM and, when ADM joined RSV in 1978, were split into two companies working under existing labels: NDSM would become responsible for building new ships, while all the repair work of the NDSM would go to the ADM, which would become solely a ship repair facility. ${ }^{40}$ The president-director of RSV (former politician and minister Dirk Stikker), as well as other members of the executive board, preferred to close NDSM at that point. However, this was unthinkable for the Amsterdam city government as well as for the national government: "[The Ministry of] Economic Affairs was against such rigorous actions. In the social-political climate of these days such far reaching measures were absolutely impossible," as Stikker later explained during the parliamentary inquiry. ${ }^{41}$ The position of the Ministry of Economic Affairs was actively supported by the Ministry of Social Affairs, which took it for granted that "their policy was a derivate of the Economic Affairs priorities as given." 42

The industrial sector of the Netherlands as a whole was severely affected by the recessions of the 1970s. The textile, clothing, and shoemaking industries lost about 70 percent of their workforce between 1970 and 1984. Shipbuilding and engineering, which were at the heart of the industrialization policy of the 1950s, were struggling with stagnating output. The official industrial policy of the Netherlands was ended in 1963, but this did not end the state's involvement in industry. The government launched new policies—which have been labeled as "industrial policies without a plan" ${ }^{43}$-in which larger firms were

38. Kamerstuk II 1984/5, 17718 (RSV inquiry), nr. 16, 30, 31 and nr. 21, 5.

39. Kamerstuk II 1984/5, 17718 (RSV inquiry), nr. 16, 93.

40. Van der Velden, "The Dutch Shipbuilding Industry”; Kamerstuk II 1984/5, 17718 (RSV inquiry), nr. 16, 171, 172; Van Romburgh and Spits, Nederlandsche Dok en Scheepsbouw Maatschappij.

41. President-director Stikker in Kamerstuk 1984/5, 17 718, nr. 21, p. 1422.

42. Wassenberg, Dossier RSV, 224, 225.

43. Van Zanden, “The History of an Empty Box,” 185. 
created in an attempt to increase international competitiveness. Inspired by the UK example of the Industrial Reorganisation Corporation, the Dutch employers asked the Dutch government to set up a similar organization: in 1972, the tripartite (consisting of unions, employers, and the government) Nederlandse Herstructureringsmaatschappij (Dutch Reorganization Corporation) was founded. The Reorganization Corporation's goal was to help labor-intensive medium-sized firms-for example, in cigar making, leather shoes, and textiles-to compete in an increasingly open world market by merging them into large firms and restructuring them. ${ }^{44}$ The corporation proved to be unsuccessful, because funding remained limited and the differences between enterprises were much larger than anticipated. This conglomeration and restructuring strategy was also taken up by the large industrial companies of the Netherlands (i.e., Philips, Akzo, OGEM, Van Gelder). Restructuring proved difficult, as making people redundant was "frowned upon" in the 1970s, as business historian Keetie Sluyterman argued. ${ }^{45}$ As a result, the government was pulled into state aid and subsidizing individual companies. ${ }^{46}$ Between 1975 and 1985, approximately €6 billion (in 2012 prices) in various kinds of aid were provided to individual companies, including large manufacturers, such as DAF, Volvo Car, Fokker, Stork, and Hoogovens. ${ }^{47}$

Nonetheless, the sector that was subsidized the most was the shipbuilding sector. ${ }^{48}$ In the 1970 s the RSV conglomerate was severely hit by the effects of the oil crises and encountered stiff competition from Southeast Asia. Over the years, the national government supported the conglomerate with 2.7 billion guilders, without reporting the payouts to Parliament. However, when the restructuring process did not show the expected results, the executive board came to view the problems primarily as a government concern, as it was the government who had ordered the maintenance of high employment rates. The executive board therefore expected to receive more state subsidies, favorable loans, and investments in return. Alternatively, as Jan van den Brink (a member of the supervisory board) stated in 1977:

Here one has to deal with participation, in which the general concern for employment plays a role. In that interest, RSV did not cut jobs and did not restructure at such a pace as was economically necessary.

44. Ben Dankbaar and Velzing, "Industriebeleid in Nederland," 7; Hesseling, "Strategische besluitvorming," 180-182, 263-266

45. Sluyterman, Dutch Enterprise in the Twentieth Century, 194.

46. Sluyterman, Dutch Enterprise in the Twentieth Century, 146.

47. Van Zanden, Een klein land in de $20^{e}$ eeuw; Dankbaar and Velzing, "Industriebeleid in Nederland," 9.

48. Van Zanden, “The History of an Empty Box,” 187. 
The company could expect the government, which with RSV conducted and supported this policy, to take its responsibility and accept the consequences. ${ }^{49}$

The president of the supervisory board, Jan de Vries, testified to the parliamentary inquiry: "I assumed that because of how RSV workedand I know that it is somewhat overstated-that this social workplace would not fall over because of large scale socio-political considerations." 50

By December 1977, the situation had once again worsened as it became clear that the crisis was not a temporary one. Thus, any hope that by 1980 a new equilibrium would be found in the market with higher prices proved to be futile. Moreover, RSV had demonstrated itself unable to lower its costs by increasing productivity and efficiency. It also became clear that the losses of the division for building large, new ships was damaging the conglomerate as a whole. The government established a tripartite "policy committee" (Beleidscommissie) made up of civil servants, dockyard owners, and unions tasked with making recommendations for reducing the overcapacity in shipbuilding. The committee was unanimously in favor of closing the economically weakest yards, which would make 2,000 people in Amsterdam (and 2,500 in Rotterdam) redundant. In return the RSV would receive 800 million guilders from various forms of state aid, and on top of that the Ministry of Social Affairs would support the discharged workers. ${ }^{51}$ This quickly led to a new controversy: the north-south conflict, in which an entire yard in either Amsterdam or Rotterdam would need to be closed. The Amsterdam-based NDSM was chosen for closure. This decision led to serious tensions within the unions: The local Amsterdam branch pleaded to leave the Beleidscommissie, while the Rotterdam branch pleaded to stay in. ${ }^{52}$

The 1978 attempt to close the NDSM met stiff opposition in Amsterdam, not only from the local trade union; all political parties from the local council sympathized with and encouraged the workers, who in a famous strike occupied the shipyard. The strike was organized by the local branch of the biggest Dutch union NKV-NVV (known as FNV from 1981) and was not backed by solidarity strikes elsewhere in the country. The future of the ADM was intentionally included in these actions, which were supported by other local groups, such as municipal workers of neighboring cities and the women's movement. Strikingly,

49. Kamerstuk II 1984/5, 17718 (RSV inquiry), nr. 18, 225 and 226.

50. Kamerstuk II 1984/5, 17718 (RSV inquiry), nr. 21, 1185.

51. Wassenberg, Dossier RSV, 229.

52. Strath, The Politics of De-industrialization, 163, 164, 173-175. 
the European Economic Community was attacked in the protests as one of the driving forces behind the attempts to close the shipyards. ${ }^{53}$ Moreover, in response to the protests, the city government announced it was prepared to invest money in the NDSM. Alderman Enneüs Heerma of the Christian Democrats (CDA) and the unions were the architects of a plan in which the ADM repair facility, which seemed profitable, could be used to cushion unemployment by taking over unprofitable parts of the NDSM. ${ }^{54}$ The fact that the occupation-strike was frequently visited by national politicians canvassing for provincial and senate elections contributed toward an overwhelming majority of seats from both the opposition and the coalition in national Parliament to speak out against the closure of the two Amsterdam dockyards. ${ }^{55}$

Consequently, a part of the NDSM was saved in the form of a small new company named Nederlandse Scheepsbouw Maatschappij (NSM), in which only 400 of the original 3,000 NDSM workers found employment. The ADM management was dead against this solution, but was overruled by the Ministry of Economic Affairs and the RSV board of directors, which received an extra aid packet to adjust the measures in Amsterdam. ${ }^{56}$ Nine hundred fifty NDSM workers were transferred to the ADM as part of a social plan for NDSM workers. ${ }^{57}$ The state and the city of Amsterdam became shareholders of NSM; Amsterdam bought the same number of shares that the national government already possessed and guaranteed loans. ${ }^{58}$ The NSM was also promised orders from the RSV conglomerate, but all parties involved seemed to be aware of the fact that this would not be the last attempt to rescue attempt of NSM, or RSV. ${ }^{59}$

\section{The European Crisis in Shipbuilding in the 1970s}

The overall confidence in Europe that building supertankers would rescue their struggling shipbuilding industry was based on the years 1967-1973, when the demand for super oil tankers was much larger

53. Van Romburgh and Spits, Nederlandsche Dok en Scheepsbouw Maatschappij, 62.

54. "Amsterdam wil in nieuwe werf delen: Nieuwe hoop voor NDSM," NRC Handelsblad, September 11, 1978; "Amsterdam bereid tot steun werfcombinatie," De Telegraaf, September, 11, 1978, 1.

55. See Rijksmuseum, Foto-opdrachten Nederlandse geschiedenis: documentatie: Verkiezingsstrijd '81; photos of Paul Babeliowsky; Wassenberg, Dossier RSV, 244 .

56. Wassenberg, Dossier RSV, 230, 243, 244.

57. Strath, The Politics of De-industrialization, 178.

58. Kamerstuk II 1980/81, 14 969, nr. 65.

59. Kamerstuk II 1984/5, 17718 (RSV inquiry), nr. 16, 487. 
than the supply. This made the real value of a delivered tanker higher than the contract price. As a result, a speculative market of preordered tankers emerged. ${ }^{60}$ The first oil crisis of 1973 liquidated this market and, due to the significant time lag in shipbuilding, overproduction drove the prices in shipbuilding down after 1973. The demand for Western European tankers diminished further as new South Asian competitors could produce ships at a much lower price. The supergroupings and other conglomerates did not deliver on the promises of cost sharing and modernization, and thus became heavily subsidized conglomerates. The subsidies were initially given to enable shipyards to weather the storm of the first oil crisis, but when the market did not recover, they quickly became a structural policy tool to protect employment in the dockyards across Europe.

Government pressure to form shipbuilding and industrial conglomerates can be observed in many Western European countries. From the mid-1960s a common belief emerged that stiff competition-at that time with Japan-could be countered by merging individual companies into regional groups. In doing so, companies could modernize by sharing the costs of research and development, as well as construct large ships, which needed new, large, dry docks that were expensive to build. This regionalization was typically accompanied by subsidies for reorganization, the commissioning of ships, and low-interest loans for ship purchases. For example, in the United Kingdom the formation of super-groupings was adopted by the government, which steered decision making in individual companies; mergers were guided by coordinating and regulatory boards and committees. In 1977, shipbuilding was almost completely nationalized in the United Kingdom. ${ }^{61}$

France is also an insightful example. Initially, the liberal president Valéry Giscard d'Estaing (1974-1981) introduced a new industrial policy that decreased direct subsidies to shipbuilding. However, three years later in 1977, aid was resumed after intensive lobbying. France did not follow a concentration policy: All five shipbuilding production sides were maintained in order to support the economy and employment in the regions. From 1977 onward, a cartel was all but officially formed; the cartel gave orders to the weakest company and decided to keep its production capacity under 70 percent. $^{62}$

Shipbuilding in West Germany was a small sector on the federal level, but responsible for 15.4 percent and 6.4 percent of the total employment in Bremen and Hamburg, respectively. Moreover,

60. Connors, "The Decline of British Shipbuilding," 35.

61. Connors, “The Decline of British Shipbuilding”; Parker, The Official History of Privatisation, 202.

62. Warlouzet, "The Collapse of the French Shipyard of Dunkirk." 
70 percent of Germany's shipbuilding capacity was produced by just five private companies, whose shipyards were brutally hit by the declining demand and overproduction of the 1970s. Between 1975 and 1984, capacity was reduced by 60 percent, and the dockyards started a process of coordinated specialization. This reduced the number of jobs considerably; in Bremen one-third of the jobs in shipbuilding disappeared between 1975 and 1982. The consolidation strategy is also visible here, for example, in the attempts to merge the big Bremen dockyards of Weser and Bremen Vulkan and the formation of a Verbund-a consortium with the shipping company Hapag-Lloyd. ${ }^{63}$ It was seen as the solution for the survival of the Bremen shipbuilding industry. However, it also illustrated how the company had become too big to fail. As a member of the executive board told Bremen's Parliament in a parliamentary inquiry of 1998: "The managers of the shipyards knew that the policy of the Land was to do everything possible to maintain jobs." 64

\section{The Public Turn in European State Aid of the 1980s}

The political economists Hubert Buch-Hansen and Angela Wigger have convincingly argued that state aid is "deeply political and needs to be understood in a broader context." ${ }^{65}$ This notion has been reinforced by the French historian of globalization Laurent Warlouzet, who studied the influence of neoliberalism on the EC and its state aid policies and labeled this policy field as "the main vehicle for a neoliberal transformation of Europe. ${ }^{" 66}$ However, as the neoliberal change has come to include a great variety of things that occurred from the late 1970s onward, we need to study in depth and in detail whether a policy paradigm shift-from Keynesian to neoliberal policy_took place, and if so, why, how, and in what form. This can be done by analyzing the general changing policy discourse and the policy area-specific discourses and their effect on policy theory and policy in practice. ${ }^{67}$ In doing so, we can find out whether a change in all three dimensions-politics, policy, and

63. Wolf points out that: "The history of Bremer Vulkan is similar to the transformations in the West German shipbuilding industry in general." Wolf, "Bremer Vulkan,” 117.

64. Seevaratnam, Governing the Shipyards, 59-73, 133-150, quote p. 136. In 1996 the Parliament (Die Bürgerschaft) of Bremen introduced parlamentarischen Untersuchungsausschuß “Bremer Vulkan.” The report of the parliamentary inquiry committee was delivered in 1998.

65. Buch-Hansen and Wigger, "Revisiting 50 Years of Market-Making."

66. Warlouzet, Governing Europe, 13, 156-181; Warlouzet, "Competition."

67. Hall, "Policy Paradigms." 
polity—did indeed take place, as well as who was responsible for it. We argue that such a change did take place and that the role of the EC was crucial. $^{68}$

Shipbuilding was one of the few economic activities clearly specified in the articles of the European Economic Community's foundational treaty (EEC Treaty) of Rome (1957), where it was stated in article 93(3c) that aid to shipbuilders to compensate for the loss of customs protection should be "progressively reduced." ${ }^{69}$ Up until 1973, the EC was not very active in promoting competition or in curtailing state aid. The first oil crisis of 1973 and increasing competition in shipbuilding even led to a sharp increase of state aid measures in the member states, which in turn made it impossible for the EC to enforce its state aid rules. State aid was seen as a legitimate way to provide social policy and to prevent unemployment by member states, as well as (to some extent) the EC and the European Court. Throughout the 1970s, the role of the Directorate-General (IV) for Competition was actively hindered by member states and the official obligation to inform the EC of new state aid was widely ignored up until the early 1980 s. ${ }^{70}$ DG IV "had been reduced to asking for information [on state aid] and could do little more than plan policy in the abstract, given the way that member states flagrantly disregarded the rules and rulings, especially where declining industries such as steel, shipbuilding and textiles were concerned.",71

The EC started to change its view after the second oil crisis of 1979, when it became clear that protective measures were not temporary, as the European regulations required them to be. Perhaps more importantly, informed by new economic theories, the belief grew within the EC that state aid was a form of market distortion that prevented economic recovery. ${ }^{72}$ This became visible in the 1978 declaration by the EC, which stated that the economic problems of the member states were "of a basic structural nature" and that they had to be addressed before economic recovery could begin. The EC was very clear in dismissing Keynesian solutions in the form of state aid to overcome the crisis. ${ }^{73}$ It had three "undeniable reasons" for this:

(i) The customs union would be quite useless and would collapse if Member States could invalidate it by granting aids; (ii) the Common Market makes little sense unless businesses tackle the market on the strength of their own resources without any aid to distort competition

68. Buch-Hansen and Wigger, "Revisiting 50 Years of Market-Making,” 22.

69. Article 93 3c, Treaty of Rome (1957).

70. López, The Concept of State Aid, 49, 50.

71. Middlemas, Orchestrating Europe, 503.

72. López, The Concept of State Aid, 50-52.

73. López, The Concept of State Aid, 50, 51. 
between them ... and (iii) lastly, and as a corollary, a system which leaves the field open for competition and does not allow aids to interfere with the optimum distribution of production factors is essential to economic and social progress. ${ }^{74}$

As a second step, in 1980 the EC wrote a letter warning the member states about a drop in the rate of notifications of planned state aid to the EC, such notifications being an obligation under the EEC Treaty. Some countries failed to notify at all, while others gave the EC insufficient time to respond. ${ }^{75}$

The appointment and role of a new commissioner for competition, Frans Andriessen (1981-1985), serves as an example of the changing role of the EC as well. Andriessen was a Christian Democrat and a former minister of finance in the Netherlands who had resigned in 1980 after the center-right coalition government decided to not back his monetarist policies and pleas for budget cuts to counter the economic recession-the biggest defeat of his career. Andriessen was only 51 and therefore eager to find a new job. He knew little about the EEC or the EC; however, after talking to experienced leading EEC civil servants Edmund Wellerstein and Max Kohnstamm, he opted for commissioner of competition, at that time still a minor post. ${ }^{76}$ It was a period of Eurosclerosis and low trust in EC chairman Gaston Thorn (former prime minister of Luxembourg). To reclaim ground, the EC focused on two sectors—steel and shipbuilding-as it had a history of legislature in those areas. Additionally, aid from member states to those sectors was substantive. ${ }^{77}$

Andriessen was aware that the role of DG Competition had to be changed: "Competition was a completely closed DG. My predecessor was a man quite tight-lipped apparently. And I opened the window.",78 His senior staff clearly saw the change. His deputy director-general, Jean Louis Cadieux, noticed that "with Andriessen you saw a change in politics, a will to be more determined." "79 Andriessen thought that DG IV had operated too "abstractly ... theoretical[ly]." He appointed Manfred Caspari as director-general. "Caspari was more open, he was more of an entrepreneur who had a lot of knowledge of what really happened in the practical economy, not in theory, but in the real-life economy." ${ }^{80}$ Caspari shared his commissioner's energy and proposed a

74. COM (78) 221 final, AEI.

75. Cownie, "State Aid in the Eighties," 247.

76. Merriënboer, "Een monument van een commissaris," 212, 214, 230.

77. HAEU, interview with Cadieux, 6, 7, 21.

78. HAEU, interview with Andriessen, 8.

79. HAEU, interview with Cadieux, 10.

80. HAEU, interview with Andriessen, 9. 
clear agenda for state aid reform: "This sector was totally neglected, you had to reach through more vigorously now." ${ }^{81}$ Retrospectively, Caspari stated: "The first year in which I took office as Director-General, I made the Commission take more negative decisions on state aid than there had been in the whole period since the founding of the EEC Treaty." ${ }^{\text {, }}$

The changing views on market distortion and state aid were first tested in the steel industry, which had structural problems very similar to those of shipbuilding (i.e., overproduction and an excess of production capacity). Steel production was regulated through the European Community of Steel and Coal Treaty, which held out the possibility of forming a cartel in times of a "clear crisis." However, a groupe d'analyse made up by Commissioners Andriessen (Competition), Davignon (Internal Market, Industrial Affairs), and Ortoli (Economics and Finance) presented "Plan Davignon" in 1978, in which steel mills were closed in exchange for a final injection of state aid and a soft landing in the free market through a temporary system of minimum prices. The DG Competition was given the role of implementing the system of minimum prices. ${ }^{83}$ The EC succeeded in using the cartel to implement a new neoliberal policy of competition and abolishment of state aid.

Shipbuilding was the second large dossier that the DG Competition took on; the Directorate profited from the preparatory work done in the steel industry. Director-General Caspari believed that the problems were similar and that there was a window of opportunity:

This [shipbuilding] was a sector where we took care of it relatively early, because it had become necessary and because of political pressure. We had of course the great advantage that the EC could negotiate directly with the Koreans and about the aid systems. So that one could say: "When you do not change your system, then we have to approve aid again." That was primarily against Korea. And it was interesting: as soon as the Community had implemented such a system, the OECD also started discussing how to organise this. So shipbuilding, that was the first sector in which you could systematically could take care of [state] aid, because of this pressure. ${ }^{84}$

Based upon its experience in the steel industry, DG IV devised a comparable scheme for shipbuilding. In the words of Caspari: "First, we approve a rationalisation cartel for decommissioning capacity. And secondly, as long as the market recovery measures are in progress, no

81. HAEU, interview with Caspari, 30.

82. HAEU, interview with Caspari, 17.

83. Feltkamp, "State Aid from the 70s to the 90s"; Rocca, "Four Vignettes,"; HAEU, interview with Cadieux, 21.

84. HAEU, interview with Caspari, 18. 
penny [of state aid] will be approved." The formula of a rationalization cartel and decline of further aid was also used later in "nonessential" sectors with "crazy overcapacity," such as textiles, paper, and synthetic fibers. $^{85}$

To implement this new policy for shipbuilding, two new directives were introduced in quick succession: the fifth directive in 1981 and the sixth directive in 1987. Both had the aim of banning state aid and promoting free international trade. The EC by now viewed the problems in shipbuilding as "structural rather than conjunctural." This could only be overcome by seriously reducing overcapacity, although the EC was aware that shipbuilding was-for some regions-the only industry and therefore "reduction [could not] take place too rapidly" in those areas. ${ }^{86}$ State aid would still be permitted to protect vulnerable regions. The consequences were, however, clear and harsh: In 1985 overcapacity was calculated to be a third of the complete production capacity, and the EC forecast that 30,000 jobs would be lost in shipbuilding before 1990. The fifth directive aimed to control state aid by making it transparent and, as a result, aid packages were reduced and economically rationalized. From 1985 onward, a reorientation of state subsidies became apparent, and member states started to withdraw or modify their aid to industry. ${ }^{87}$ However, indirect aid to shipbuilding in the form of credit facilities or loan guarantees to shipowners remained possible, so the sixth directive (1987) pushed further on restructuring and capacity reduction by curtailing all government aid to a maximum of 28 percent of the price of a contract. The form of aid (indirect or direct) was no longer an argument, ${ }^{88}$ and the ceiling of 28 percent was annually reviewed and in later years lowered.

Indeed, dramatic changes were witnessed, which began during the Andriessen-Caspari years. In the decade before 1981, state aid was only prohibited in twenty-one cases, but in the four years between 1981 and 1985, the EC prevented fourteen cases. ${ }^{89}$ On top of that, in 1983 Andriessen decided that from then on the EC would actively recover illegally granted state aid. ${ }^{90}$ The famous Boussac ruling by the European court in 1988 emphasized the EC's determination on this matter, forcing the French government to repay more than 300 million French francs (approximately €82.5 million in 2013) of unlawful aid to the textile producer; such a repayment by member states would have

\footnotetext{
85. HAEU, interview with Caspari, 19.

86. Directive 87/167/EEC.

87. López, The Concept of State Aid, 55, 56.

88. Kelly et al., "Issues and Developments in International Trade Policy," 80.

89. Middlemas, Orchestrating Europe, 504.

90. Cownie, "State Aid in the Eighties," 247.
} 
been unthinkable only a few years prior. ${ }^{91}$ In historiography it has therefore been suggested that "the revival of confidence inside DG IV [Competition] after 1981" was crucial for this change. ${ }^{92}$

The signing of the Single European Act (1986) and the progression toward the establishment of the European single market (1992) were further stimulants. They created an "economic and intellectual context" wherein a forceful competition and anti-state aid regime could emerge. ${ }^{93}$ This was not necessarily a given, because the Single European Act only discussed state aid reform briefly, as cooperation between companies was emphasized more heavily. ${ }^{94}$ The DG Competition was tremendously helped in its effort to put limitations on state aid by the DG's interpretation of the Single European Act and the road map for establishing a single market in 1992. In the white paper on the completion of the internal market (June 14, 1985), this new policy is clearly visible:

It will be particularly important that the Community discipline on state aids be rigorously enforced. There are tendencies to spend large amounts of public funds on state aids to uncompetitive industries and enterprises. Often, they not only distort competition but also in the long run undermine efforts to increase European competitiveness. They represent a drain on scarce public resources and they threaten to defeat efforts to build the internal market. ${ }^{95}$

Commissioners Peter Sutherland (1985-1989) and Leon Brittan (19891993) took significant advantage of the occurring paradigm shift, which resulted in what the political scientists Umut Aydin and Kenneth Thomas have labeled a "public turn," in which the DG Competition "started to more forcefully tackle anti-competitive behaviour of member state governments in the form of state aids and public monopolies." ${ }^{96}$ The EC gained support for its changed state aid doctrine through rulings by the European Court of Justice and received explicit support from the European Parliament. ${ }^{97}$ From 1992 onward, the EU started to export its now vested state aid rules to, for example, the World Trade Organization, as well as to Central and Eastern European countries aspiring to EU membership.

91. López, The Concept of State Aid, 195.

92. Middlemas, Orchestrating Europe, 503-504.

93. Warlouzet, "Competition," 295-296.

94. Warlouzet, "The Rise of European Competition Policy," 18

95. White Paper Internal Market COM (85) 310, AEI.

96. Aydin and Thomas, "The Challenges and Trajectories of EU Competition Policy,” 538; Warlouzet, “Competition,” 298, 299;

97. López, The Concept of State Aid, 52, 195. 


\section{Amsterdam Fights but Parliament Loses Its Appetite for Subsidies (1981-1986)}

How did this public turn affect the Amsterdam shipyards? On September 17, 1980, the European Court ruled against the Netherlands' claim that its aid to the tobacco firm Philip Morris was legal. This famous ruling would have a great effect on all forms of state aid, as it showed the Court's determination that the EC had the power to decide whether state aid was admissible. The Court ruled that market distortion was only allowed to accomplish Community goals. The treaty allowed this distortion for areas with high unemployment and abnormally low standards of living. ${ }^{98}$ Because the standard of living in the Netherlands was well above the European average, this could potentially make aid to Dutch shipbuilders illegal. The second reason the Philip Morris case became very famous was that it was a "political landmark ... a public statement about DG IV's right to restrict the freedom of national and subnational aid-donors in choosing where and when to grant subsidies." 99

From 1980 onward, we see a clear change in aid policy. First, the Dutch minister of economic affairs started to decrease new aid attempts. The government's reluctance led to tensions between government representatives on the one hand and the owners and the unions on the other hand. The owners kept actively seeking state aid to support their dwindling capital position, while from 1978 onward the unions lost their belief in economic restructuring and started to follow a "survival strategy" aimed at keeping dismissals at a minimum. ${ }^{100}$ In 1981 , the FNV left the tripartite committee for the national restructuring of shipbuilding to wholeheartedly support local protests, but it also meant that the union lost its influence on softening the impact of closures. ${ }^{101}$ After the famous 1978 NDSM strike, strikes were rarely employed in shipbuilding. According to Sjaak Van der Velden, who has researched strikes in shipbuilding, workers had lost confidence because of the crisis within the industry. Even during the national strikes of 1980 and 1982, most of them continued working in their yards. ${ }^{102}$ This was another reason that the unions could not play a large role in softening the impact of closures. The attempt in 1984 of the FNV to form a unified front with the owners of the yards came too late, as by 1984 the

98. ECLI:EU:C:1980:209.

99. Michelle Cini as quoted in Thomas, Competing for Capital, 113, 114.

100. Wassenberg, Dossier RSV, 228.

101. Strath, The Politics of De-industrialization, 180.

102. Van der Velden, "The Dutch Shipbuilding Industry," 233, 234, 238. 
owners had adopted the same position as government "that the market ultimately had to decide on the future of the industry."103

In the meantime, NSM continued to struggle in a declining market, the EC saw it as a "crisis within the crisis" with prices and orders taking another plunge, while overcapacity increased even further. ${ }^{104}$ In February 1981, Parliament unanimously asked the government to sustain aid giving to NSM. However, the minister of economic affairs, Gijs van Aardenne, was reluctant to do so. ${ }^{105}$ The board of directors was unpleasantly surprised, it had counted on support: "Perhaps we were too much an entrepreneur and too little a politician. When we knocked at the door of Economic Affairs we had the impression that the government would meet our wishes."106 After conducting his own research, Van Aardenne "had the opinion that for NSM there were not enough future opportunities to justify additional government aid." The city of Amsterdam continued to ask for aid and even had conceived a rescue plan worth at least 25 million guilders (the equivalent of approximately $€ 23.5$ million in 2018). On the same day that the city published its plan, the DG Competition (headed by Andriessen) voiced its concerns to the minister of economic affairs: Aid from the city of Amsterdam to NSM would also be qualified as state aid. This was an additional reason for Minister Van Aardenne to not approve it. ${ }^{107}$ Alderman Heerma was furious: "It is crystal clear that this government only tries to save Rotterdam shipbuilding and drops Amsterdam like a hot potato." ${ }^{108}$ Parliament was furious about Van Aardenne's letter, which was condemned by all parties. ${ }^{109}$ This condemnation had no effect on DG IV, whose importance and influence continued to growth, which is an indication that the polity dimension (i.e., the shifting state structure and power relations between the actors) had changed further.

This became further evident when DG IV opened a formal investigation in December 1981, as it had doubts whether earlier aids were in compliance with the EC treaty. The Dutch government regretted this step; in its mind, it had always informed the EC on aid packages. Civil servants had discussed this aid package in the European multilateral meeting on shipbuilding aids, in which none of the other member states had opposed the aid. ${ }^{110}$ A meeting between Van Aardenne and

103. Strath, The Politics of De-industrialization, 181.

104. Com (85) 548 final, AEI.

105. Kamerstuk II 1980/1, 14 969, nr. 60.

106. As quoted in Wassenberg, Dossier RSV, 246.

107. Kamerstuk II 1980/81, 14 969, nr. 63.

108. Heerma as quoted in Wassenberg, Dossier RSV, 257.

109. Kamerstuk II 1980/81, 14 969, nr. 66.

110. NA 2.08.107, 5595, telexes to DG IV, undated [December 1981?]; January $20,1982$. 
Andriessen on January 27, 1982, did not change Andriessen's view on possible "inadmissible" state aid to NSM as well as ADM. In 1982, ADM also needed an additional 36 million guilders (worth €32 million in 2018) to survive. The city of Amsterdam was willing to loan half of the money, but Minister Van Aardenne refused to provide any money in November 1982, even though he thought the size of Amsterdam's harbor justified a repair facility. The main reason was that the DG Competition had informed Van Aardenne that a loan to prevent imminent bankruptcy would not be accepted while earlier aid packages were still being researched. ${ }^{111}$ DG IV had started a formal investigation into incompatible state aid for ADM just a month prior. ${ }^{112}$ Events unfolded so quickly that the Dutch government was not able to keep DG IV fully informed in a timely way. ${ }^{113}$ Meanwhile, inside the Ministry of Economic Affairs, a policy change had already set in. From 1982 onward, civil servants in multilateral meetings on state aid in shipbuilding told their colleagues from DG IV and member states that they would phase out aid completely by 1985 . These Dutch officials now also supported the EC in presenting its new sixth directive to prevent a "situation of state aid anarchy."114

The beliefs of Parliament started to change as well; in 1980 Parliament was still highly in favor of state aid, and in 1981 Parliament had condemned minister Van Aardenne's aid refusal. Within a year that position changed. When the new coalition government of CDA and Liberals (VVD) (1982-1989)—who were united in their goal of reducing government spending and debt by promoting privatization-came to power, the ruling parties were now more skeptical about aid. ${ }^{115}$ In a debate on December 8, 1982-with the mayor and aldermen of Amsterdam in the public gallery-CDA felt that the "government should only play an additional role" in business affairs and "governments have only strength against market forces." Meanwhile the VVD, in the words of $\mathrm{H}$. H. Jacobse, argued that "distortion of competition is almost always the unintentional by-product of this type of aid, and distortion of competition is most certainly not my only objection." Despite these objections, CDA and VVD also felt that aid should be considered if an independent report acknowledged that a profitable business in ship repair was feasible. ${ }^{116}$ However, the position of the opposition parties (holding 69 of the 150 seats) had not yet changed significantly. The

111. Kamerstuk II 1982/83, 17600 XIII, nr. 15.

112. NA 2.08.107, 5596, formal notification of EC, October 13, 1982.

113. NA 2.08.107, 5595, telex to Commissioner Andriessen, January 31, 1983.

114. NA 2.08.107, 5595, Verslag June 10, 1982, 1.

115. Kroeze and Keulen, "Managerpolitiek”; Keulen and Kroeze, "De Europese Commissie."

116. Handelingen II 1982/83 1019, 1020. 
Communists pointed to the stream of telephone calls, letters, and telexes from companies, municipalities, and workers who pleaded for additional aid. Labor (PvdA), the largest opposition party, explained that a repair facility was a public utility for the whole harbor and that it saw no distinction between public and private ownership. Labor simply did not believe that the EC could have any objection, as "you do not raise objections if you want to pursue a policy that [is] positively focused." 117

In January 1983, a report by a committee of so-called wise men addressed opportunities to keep a repair facility in the Amsterdam harbor, at a cost of at least 50 million guilders (approximately €43.10 million in 2018) in subsidies to ADM. For this reason, Minister Van Aardenne announced "the government has taken the position that while it recognises the importance of ADM for the region of Amsterdam, it must take its national responsibility and can go no further than the 6.4 million guilders that my predecessor already has provided as a guarantee." ${ }^{118}$ In a debate in the Senate, Van Aardenne explained: "Brussels is critical of these kinds of affairs. It is rightly so, because it assesses government support and whether that is aid from the national government or from the municipality does not matter that much. What matters is the assessment of possible distortions of competition."119

This decision was met with disbelief by the Amsterdam city government. In an 111 hour-long attempt in front of TV cameras, two aldermen (Heerma from the CDA and Schaefer from the PvdA) haggled for funds from the porter's lobby of the ADM. Workers handed in parts of their wages and members of the public went to the city hall to donate money. ${ }^{120}$ The last 15 million guilders was found when the city bought the dockyard infrastructure from ADM to lighten the burden. ${ }^{121}$

The Amsterdam protests influenced Andriessen's initial decision. On April 28, 1983, it became known that Commissioner Andriessen approved aid for ADM after all, although the EC was not notified about Amsterdam's purchase of the docklands. In the words of Minister Van Aardenne: "It took a lot of effort to persuade the EC to come to a favourable decision on ADM." Furthermore, because of this decision, he "saw no objection to provide restructuring aid to other parts of the former RSV conglomerate." ${ }^{122}$ Meanwhile, Van Aardenne never provided new aid, probably because the EC had concluded that they would monitor state aid to shipbuilders even more strictly in 1983, but also

117. Handelingen II 1982/83 1015, 1018.

118. Handelingen II 1982/83 1603; Kamerstuk II 1982/83, 17600 XIII, nr. 25.

119. Handelingen I 1982/83, 531.

120. Ilse Bos, “Enneüs Heerma," Groene Amterdammer, no. 40, October 5, 1994.

121. Kamerstuk II 1982/83 17600 XIII, nr. 135, 3, 4.

122. Handelingen II 1982/83 3700. 
because Dutch civil servants had concluded that subsidizing was to no avail. They told their European colleagues in June 1983: "The situation of the shipbuilding sector is so difficult world-wide that every national attempt of aid will be lost. A national solution is no longer possible, everything should be seen as part of the total picture."

The RSV conglomerate filed for bankruptcy in the same year, after which Parliament initiated an inquiry on the causes of this failure, which became a national media event. The public summaries of the questioning drew a great audience and culminated with a 6,000-page report issued in 16 volumes and weighing 13 kilograms, published in December $1984 .{ }^{124}$ The inquiry committee, with members from all major parties and covering the political spectrum from the Communist party to the orthodox Christian conservative SGP party, reached a joint conclusion in which a change in policy is visible. For the first time, all major parties agreed that "it is doubtful whether the struggle to keep open the shipbuilding capacity that has been unprofitable for years as long as possible could, for social reasons, be regarded as an acceptable policy alternative." The committee accepted that the problems in shipbuilding were structural and that "even economic recovery would not lead to a viable Dutch shipbuilding industry." Pursuing a policy of keeping the shipyards open in those circumstances had only led to a "constant source of uncertainty and a long series of disillusions.", 125 Therefore, the inquiry committee proposed a new policy for state aid:

In order to avoid hopeless aid operations, the granting of state aid should be subject to a number of conditions: there has to be a prospect of a return to profits, the operation has to be a one-off (so no repetitive cases) and the aid that will be allowed needs to be a reasonable amount that does not exceed several tens of thousands of guilders per job. The support for RSV's shipbuilding construction did not meet any of these conditions. The operation started in 1976 required more support each year and in a single case ultimately threatened to exceed an amount of fl. 400,000 [€333,334 in 2018 prices] per job. It lacked all proportion. ${ }^{126}$

The parliamentary inquiry showed the ineffectiveness of the massive scale of state aid that was completely running out of control, ${ }^{127}$ results that acted as a catalyst for Parliament to move away from support for aid (in order to maintain employment) to a blanket refusal of aid and embracing the belief that market forces should run their course. The

123. NA 2.08.107, 5596, Verslagen June 7, 1983; September 21, 1982.

124. VPRO, De RSV-Enquête; Strath, The Politics of De-industrialization, 156.

125. Kamerstuk II 1984/5, 17718 (RSV inquiry), nr. 16., 462.

126. Kamerstuk II 1984/5, 17718 (RSV inquiry), nr. 16., 462.

127. Kroeze and Keulen, "More exciting than Watergate." 
inquiry, therefore, finalized a major shift in national economic policy in which "non-intervention ... became the norm." ${ }^{128}$ No longer would the protection of employment in vulnerable (urban) regions be a major factor in industry economic aid decisions, and loans to certain industry sectors were therefore seriously trimmed down. Therefore, after a change in polity and policy, the third dimension-politics-had now also changed because of the inquiry.

Between 1983 and 1986, the RSV conglomerate was split into six companies. Amsterdam tried to sustain the two shipyards and protect employment, but new attempts to sustain credit from the national government for ADM or NSM were to no avail. ${ }^{129}$ The NSM never recovered and was declared bankrupt in May 1984. The Amsterdam alderman for economic affairs tried to restart the company once more; ${ }^{130}$ nevertheless, his final attempts also failed.

The ADM fared little better. By January 1985, the company could no longer pay its workers' wages and turned to the government once more. The minister of economic affairs stated: "In case of bankruptcy, the current financiers of the company, i.e. banks, are primarily responsible ... and for that you cannot expect a contribution from the government." ${ }^{131}$ He presented this as the lesson learned from the RSV inquiry, an opinion now shared by most parties in Parliament. Labor by now saw the bankruptcy as "unavoidable." ${ }^{132}$ The Social Liberal party D66 emphasized: "We know the RSV history. It seems that some lessons have been learned from it, even though mistakes have been made. The ADM's bankruptcy is unavoidable. Everyone acknowledges that-even the trade unions." ${ }^{133}$ The contribution of CDA is also illustrative of the change that they accorded, as their spokesman in Parliament stated: "It is widely acknowledged that the ADM has no future in its current form. We believe that a solution must be found in a position which has both feet on the ground. That means market conformity and the perspective of making profit." ${ }^{134}$ Only certain members of the small left-wing parties were still in favor of giving aid. One of them, MP Willems (PSP), stated: "I must warn again that one should not be providing aid in general. That has come to be the atmosphere after the RSV drama. We think that providing aid can be very useful." 135 The ADM repair facility, however, had to close its doors within a month, in February 1985.

128. Van Zanden, "The History of an Empty Box," 188.

129. Kamerstuk II, 184/85, 18600 XIII, nr. 87.

130. "Oud-Shell man bekijkt werf NSM," NRC Handelsblad, June 1, 1984, 13.

131. Kamerstuk II 1984/85 18600 XIII, 87.

132. Handelingen II 1984/85, 2803.

133. Handelingen II 1984/85, 2802.

134. Handelingen II 1984/85, 2805.

135. Handelingen II 1984/85, 2801. 
When the budget for economic affairs was discussed in the Senate a year later, a new policy paradigm clearly was established. The best example of this is Senator Zijlstra (CDA) who, while reflecting on the closure of ADM, pleaded to halt generic subsidies for shipbuilding as soon as possible, by introducing the metaphor of an orange, which was first squeezed, after which the collected juice was injected in the orange once more, in the idle hope that it would become a beautiful orange again. He could no longer believe this logic and "was now convinced that the government has to take as many steps back as possible."136

\section{Closing off Shipyards in Europe in the 1980s}

The closure of the Amsterdam shipyards illustrates a European development. The history of the nationalized British Shipbuilders Corporation (BS) was also one of managing decline. In 1982, half of Britain's shipyards were closed to reduce overcapacity. The cabinet of Margaret Thatcher (1979-1990) initiated the British Shipbuilders Act of 1983 to denationalize the industry and break up divisions into viable private companies, while the remaining sites were closed down. Only the warship-building shipyard-due to successful government contracts - seemed to be economically viable at that time. The same could not be said for almost all other merchant shipbuilders, whose workforces dwindled from 87,000 employees in 1977 to only 5,000 by 1987. In 1987 government ministers guided by Kenneth Clarke (who was responsible for nationalized industries) proposed to liquidate the last remaining facilities. Clarke felt that the new Sixth Shipbuilding Directive of the Community introduced such a ceiling for state aid that the UK government took it to be henceforth impossible for British shipbuilders to win further contracts. Under pressure from the Secretary for Scotland, who feared further unemployment in already highly effected areas, Thatcher was persuaded to not dissolve BS; however, this could not halt a further decline of British shipbuilding. By the end of the 1980s, BS was an empty shell of a company, its last activities either sold or scrapped. $^{137}$

France and Germany also found the EC standing in their way during their attempts to save their shipbuilding industries and maintain regional employment. In France, the closure of yards was avoided by the merging of five shipyards into two companies: the state-owned Chantiers de l'Atlantique and private company Normed. The latter also received indirect state aid; with shipyards as far apart

136. Handelingen I 1985/86, p. 428.

137. Parker, The Official History of Privatisation, 208-210. 
as 1,000 kilometers, synergy was not at the forefront of this operation-protection of unemployment was. Although voices within the Ministry of Economics could be heard calling to terminate yards to curtail overproduction, the French government promised a crowd of protesting strikers in 1984 that no one would be laid off. State aid became, however, very costly. The Cour des Comptes (Court of Auditors) calculated in 1986 that the subsidy per employee was 286,000 French francs (or €73,000 in 2013), and that subsidies were so high that it was cheaper for the French state to decline an order and accept an increase in unemployment benefits than to actually build new ships. Local authorities, one example being the case of Dunkirk, also actively supported the shipyards. Alongside the unions, they persuaded the French railroads in 1985 to order a train-ferry; a subsidy of the local authorities covered 90 percent of the costs. A year later the national shipbuilding aid policy was changed. During the term of the Liberal prime minister Jacques Chirac (1986-1988) and under mounting pressure of the European commissioner for competition Peter Sutherland, the state aid to Normed was terminated. The Liberal French minister of industries, Alain Madelin, was favorable toward the Sixth Directive on Shipbuilding, which was seen as helpful to reduce the burden of state aid for the French state. Normed could not survive, and the company was liquidated. The blow of the termination of state aid was somewhat softened by a generous social aid package and by establishing a tax-free zone in Dunkirk to stimulate employment. ${ }^{138}$

Meanwhile, in Germany, shipbuilding was the sector that benefited the most from state aid per produced product. Länder-like Bremenpaid state aid to the shipyard, as they thought it was "politicallypsychologically" unthinkable that shipbuilding would disappear. Out of fear of raising unemployment costs and loss of apprenticeships and tax revenue, the Senate of Bremen assessed it would be cheaper "to buy employment." The federal state did not share this view in the mid-1980s and was against state aid; however, as the federal state was not involved in this aid, it did not feel obliged to notify the EC. Moreover, the EC did not take a hard stance in implementing its own policies on state aid in this matter. ${ }^{139}$

After the introduction of the Sixth Directive on Shipbuilding in 1987, the DG Competition did follow up on the Bremen case after the director-general read in the media about new state aid from Bremen's Senate. West Germany's federal minister of economics told

138. Warlouzet, "The Collapse of the French Shipyard of Dunkirk," 13. 139. Seevaratnam, Governing the Shipyards, 135, 136. 
Bremen's government he "was not prepared to pull the European Commission's leg," illustrating that times were changing. By the late 1980s, the Sixth Directive and European law asserted that past illegal state aid should be repaid, stipulating that aid was only allowed when it led to capacity reduction and improved the competitiveness of a company. Therefore, any state aid procedure would be dangerous for the continuation of the aid generally and the future of the Bremen dockyards. The EC opened an investigation into German state aid in 1989, finding several measures that were incompatible with the Common Market. A year later, the EC ruled that state aid was admissible, because Bremen had stayed well under the 28 percent limit, with subsidies of 12.8 percent of the price. ${ }^{140}$ In short, the new active role of DG IV and the spreading of neoliberal ideas on state aid and failing competition, backed by rules and regulations, were clearly visible across Europe. $^{141}$

\section{Conclusion}

The closure of the Amsterdam shipyards is a good case study of a policy paradigm shift and the roles of different actors. The story of the Amsterdam shipyards fits into the European policy strategy of centralization and increasing state aid to the shipbuilding industries to prevent unemployment in the 1960s and 1970s. The Amsterdam case epitomizes the policy paradigm shift from Keynesianism to neoliberalism.

Our study shows that the process of change was promoted and countered at different governance levels: i.e., local, national, and European. As the theories of policy paradigms predicted, a new actor in the polity can change everything quite suddenly. The EC, especially in the form of the DG Competition, which became very influential, played this aforementioned key transformative role. In the process of establishing a European single market, strict state aid policies became useful. The European and national governance level, represented by Van Aardenne and Andriessen, accepted and promoted the emerging new policy discourse early on. The Netherlands was one of the first European countries in which the policy paradigm from state aid to free trade took place. This was partly because of the specific ties between the European commissioner and the Netherlands, and partly because the Netherlands was singled out in the European court case of Philip Morris. In these circumstances, Dutch civil servants changed their

140. Seevaratnam, Governing the Shipyards, 133-150, quotes pp. 135, 136, 150. 141. Middlemas, Orchestrating Europe, 505. 
views, as private discussions with European colleagues illustrate, contributing to a change at the policy dimension and a policy without state aid. The Dutch cabinet was also receptive to the European pressure, because it fit into the cabinet's wider agenda of budget cuts and privatization as a means to end the economic recession. ${ }^{142}$ The dimension of politics was the last dimension that changed. Although changing preferences can be found from 1982, it was the parliamentary inquiry that functioned as a catalyst, as it showed the immense scale and ineffectiveness of the subsidies. It led to the ultimate conclusion that the Keynesian paradigm-massive government aid to ensure job security - was no longer acceptable for the large political parties. State aid was no longer seen as social—the old Keynesian argument-but as market distortion and unprofitable-the neoliberal argument. In the Dutch case, the acceptance of the new paradigm took about five years, which is relatively quick compared with the other Western European countries, and was probably the result of both early adoption by Van Aardenne and Andriessen and the dramatic RSV inquiry. However, it is still a more gradual and multilevel interplay than many theorists of policy paradigm shifts suggest.

Strikingly, and despite the Netherlands' long tradition of tripartite bargaining in labor relations, both unions and shipbuilders did not play a major role in the shift. The unions were, first, caught in the northsouth tension and opposing local views: in 1981, they stepped out of the national consultations on restructuring. The executive and supervisory boards of the shipyards, on the other hand, were highly reliant on government loans and were in no position to protest, as well as being unwilling to play an active role and take responsibility for this unfolding failure. Certainly, after the collapse of RSV and the breakup and closure of the conglomerate, owners became competitors once again and accordingly adopted the position that market forces had to run their courses.

Finally, we have illustrated the fruitfulness of the multilevel governance approach for historical research into policy change. Both the European Community and Amsterdam were very influential in shaping the debate; they had direct contact with civil servants, ministers, and MPs who echoed their arguments. That Amsterdam did not succeed in sustaining aid can be explained through the concept of a policy paradigm shift: The change was too extensive, similar to what happened in other places in Western Europe, where state aid and subsidies were phased out and many local governments had to accept "their" shipyards being closed in the 1980s.

142. Kroeze and Keulen, "Managerpolitiek." 
Bibliography of Works Cited

Books

Ankersmit, Frank. Aesthetic Politics: Political Philosophy Beyond Fact and Value. Stanford, CA: Stanford University Press, 1996.

- Historical Representation. Stanford, CA: Stanford University Press, 2001.

Brenner, Neill. New State Spaces: Urban Governance and the Rescaling of Statehood. Oxford: Oxford University Press, 2014.

Burgin, Angus. The Great Persuasion: Reinventing Free Markets Since the Depression. Cambridge, MA: Harvard University Press, 2012.

Hooghe, Liesbet, and Gary Marks. Multi-level Governance and European Integration. Lanham, MD: Rowman \& Littlefield, 2001.

Jones, Daniel Stedman. Masters of the Universe: Hayek, Friedman, and the Birth of Neoliberal Politics. Princeton, NJ: Princeton University Press, 2014.

Kuhn, Thomas S. The Structure of Scientific Revolutions. Chicago: University of Chicago Press, 1996.

López, Juan Jorge Piernas. The Concept of State Aid Under EU Law: From Internal Market to Competition and Beyond. Oxford: Oxford University Press, 2015.

Mahoneyand, J., and K. Thelen, eds. Explaining Institutional Change. Ambiguity, Agency, and Power. Cambridge: Cambridge University Press, 2010

Middlemas, Keith. Orchestrating Europe. The Informal Politics of the European Union 1973-95, London: Fontana, 1995.

Parker, David. The Official History of Privatisation. Vol. 1, The Formative Years 1970-1987. London: Routledge, 2009.

Seevaratnam, Vijayakala. Governing the Shipyards: Europeanisation and the German Shipbuilding Industry. London: London School of Economics and Political Science, University of London, 2004.

Sluyterman, Keetie E. Dutch Enterprise in the Twentieth Century. Business Strategies in a Small Open Economy. London: Routledge, 2005.

Stone, Dan, Goodbye to All That?: A History of Europe Since 1945. Oxford: Oxford University Press, 2014.

Strath, Bo. The Politics of De-industrialization. The Contraction of the West European Shipbuilding Industry. London: Croom Helm, 1987.

Ther, Philipp. Europe Since 1989: A History. Princeton, NJ: Princeton University Press, 2016.

Thomas, Kenneth P. Competing for Capital: Europe and North America in a Global Era. Washington, DC: Georgetown University Press, 2000.

Tomlinson, Jim. Managing the Economy, Managing the People: Narratives of Economic Life in Britain from Beveridge to Brexit. Oxford: Oxford University Press, 2017.

Van Meurs, Wim. Never Mind the Gap: Comparison in Political History. Nijmegen, Netherlands: Radboud University, 2018.

Van Romburgh, C. P. P., and E. K. Spits. Nederlandsche Dok en Scheepsbouw Maatschappij. Rotterdam: ILCO, 1996. 
Van Zanden, J. L. The Economic History of the Netherlands in the 20th Century. London: Routledge, 1997.

- Een klein land in de in de $20^{e}$ eeuw. Economische geschiedenis van Nederland, 1914-1995. Utrecht: Spectrum, 1997.

Warlouzet, Laurent. Governing Europe in a Globalizing World: Neoliberalism and Its Alternatives Following the 1973 Oil Crisis. London: Routledge, 2017.

Wassenberg, A. Dossier RSV: Schijnbewegingen van de industriepolitiek. Leiden: Stenfert Kroese.

Articles, Chapters in Books, Papers, and Theses

Aydin, Umut, and Kenneth P. Thomas. "The Challenges and Trajectories of EU Competition Policy in the Twenty-First Century." Journal of European Integration, 34, no. 6 (2012): 531-547.

Bardach, Eugene. "Policy Termination as a Political Process." Policy Sciences, 7, no. 2 (1976): 123-131.

Baumgartner, F. R., B. D. Jones, and P. B. Mortensen. "Punctuated Equilibrium Theory: Explaining Stability and Change in Public Policymaking." In Theories of the Policy Process, edited by Paul Sabatier and Christopher Weible, 59-103. New York: Francis \& Taylor, 2014.

Bosscher, Doeko. "De oude en de nieuwe stad." In De Geschiedenis van Amsterdam. Vol.4, 1900-2000, edited by Piet de Rooy, 357-399. Amsterdam: SUN, 2007.

Buch-Hansen, Hubert, and Angela Wigger. "Revisiting 50 Years of MarketMaking: The Neoliberal Transformation of European Competition Policy." Review of International Political Economy, 17, no. 1 (2010): 20-44.

Connors, D. P. "The Decline of British Shipbuilding: Negotiations Between the British Government and the Scott Lithgow Company 1960-1987." Essays in Economic \& Business History, 25 (2007): 27-40.

Cownie, Fiona. "State Aid in the Eighties." European Law Review, 11, no. 4 (1986): 247-269.

Crotty, James. "Was Keynes a Corporatist? Keynes's Radical Views on Industrial Policy and Macro Policy in the 1920s." Journal of Economic Ideas, 33, no. 3 , (1999): 555-578.

Daigneault, J. M. "Reassessing the Concept of Policy Paradigm: Aligning Ontology and Methodology in Policy Studies." Journal of European Public Policy, 21, no. 3 (2014): 453-469.

Daniels, Mark R. "Policy and Organizational Termination." International Journal of Public Administration, 24, no. 3 (2001): 249-262.

Dankbaar, Ben, and Evert-Jan Velzing. "Industriebeleid in Nederland sinds 1850.” In Samen toekomst maken met techniek, edited by Ben Dankbaar and Theo van den Berg, 1-25. Hoofddorp, Netherlands: Stichting Industriebeleid en Communicatie, 2013.

DeLeon, Peter. "Public Policy Termination: An End and a Beginning." Policy Analysis, 4, no. 3 (Summer 1978): 369-392.

—. "Policy Evaluation and Program Termination." Review of Policy Research, 2, no. 4 (1983): 631-647. 
Feltkamp, Ronald. "State Aid from the 70s to the 90s-from Steel to Banking." Comp@60: 60 Years of DG Competition, accessed December 19, 2019, http:// ec.europa.eu/competition/compat60/index.html.

Geva-May, Iris. "Riding the Wave of Opportunity: Termination in Public Policy." Journal of Public Administration Research and Theory, 14, no. 3 (2004): 309-333.

Gustavsson, Eva, Ingemar Elander, and Mats Lundmark. "Multilevel Governance, Networking Cities, and the Geography of Climate-Change Mitigation: Two Swedish examples." Environment and Planning C: Government and Policy, 27, no. 1 (2009): 59-74.

Hall, P. A. "Policy Paradigms, Social Learning, and the State: The Case of Economic Policymaking in Britain.” Comparative Politics, 25, no. 3 (1993): 275-296.

Harris, Michael. "Policy Termination: Uncovering the Ideological Dimension." International Journal of Public Administration, 20, no. 12 (1997): 2151-2175.

Hesseling, Hendrik Jan. "Strategische besluitvorming in een neergaande bedrijfstak Onderzoek naar de strategische maatregelen in de krl textielindustrie in de periode 1950-2000." Dissertation, University Twente, Enschede, Netherlands, 2010.

Kelly, Margaret, Ann Kenny McGuirk, Peter Winglee, Clemens Boonekamp, Yoon Je Cho, Bernhard Fritz-Krockow, and Peter Uimonen. "Issues and Developments in International Trade Policy.” Occasional Paper No. 63. Washington, DC: International Monetary Fund, December 1988.

Keulen, Sjoerd, and Ronald Kroeze. "De Europese Commissie als motor van verandering: staatssteun, neoliberalisme en de sluiting van de Amsterdamse scheepswerven, 1976-1986." TSEG/ Low Countries Journal of Social and Economic History (forthcoming 2020).

Kroeze, Ronald, and Sjoerd Keulen. "Managerpolitiek. Waarom historici oog voor management moeten hebben." BMGN-Low Countries Historical Review, 127, no. 2 (2012): 97-112.

—. "'More exciting than Watergate, more real than Dynasty': Transparency's Rise: The Dutch RSV-inquiry and the Context of the 1980s."In History of Transparency in Politics and Society, edited by Jens Ivo Engels and Frédéric Monier, Göttingen 2020.

Ludlow, Piers. "Jacques Delors: Surfing the Crest of the European Wave." In The History of the European Commission 1973-1986, edited by Michel Dumoulin, Élisabeth Palmero, Vincent Dujardin, Eric Bussière, Piers Ludlow, and Jan Willem Brouwer, 465-473. Luxembourg: Publications Office of the European Union, 2014.

Marks, G., L. Hooghe, and L. Blank. "European Integration from the 1980s: StateCentric v. Multi-level Governance." Journal of Common Market Studies, 34, no. 3 (1996): 341-378.

Merriënboer, Johan. “'Een monument van een commissaris.' Frans Andriessen, lid van de Europese Commissie (1981-1993).” In De Nederlandse Eurocommissarissen, edited by Gerrit Voerman, Bert ter Braak, and Carla van Baalen, 207-233. Amsterdam: Boom, 2010.

Phelps, Edmund S. "Corporatism and Keynes: His Views on Growth.” In Keynes's General Theory After Seventy Years, edited by Robert W. Dimand, 
Robert A. Mundell, and Allesandro Vercelli, 91-101. London: Palgrave Macmillan, 2010.

Plehwe, Philip. "Introduction." In The Road From Mont Pèlerin, edited by Philip Mirowski and Dieter Plehwe, 1-45. Cambridge, MA: Harvard University Press, 2015.

Piattoni, S. "Multi-level Governance: A Historical and Conceptual Analysis." European Integration, 31, no. 2 (2009): 163-180.

Princen, Sebastiaan, and Paul 't Hart. "Putting Policy Paradigms in Their Place." Journal of European Public Policy, 21, no. 3 (2014): 470-474.

Princen, Sebastiaan, and Femke Van Esch. "Paradigm Formation and Paradigm Change in the EU's Stability and Growth Pact." European Political Science Review, 8, no. 3 (2016): 355-375.

Rocca, Gianfranco. "Four Vignettes." Comp@60: 60 Years of DG Competition, accessed December 12, 2019, http://ec.europa.eu/competition/compat60/ index.html.

Stephenson, Paul. "Twenty Years of Multi-level Governance: 'Where Does It Come From? What Is It? Where Is It Going?'." Journal of European Public Policy, 20, no. 6 (2013): 817-837.

Van der Velden, Sjaak. "The Dutch Shipbuilding Industry, 1950-2012." In Shipbuilding and Ship Repair Workers Around the World: Case Studies 1950-2010, edited by R. Varela, H. Murphy, and M. van der Linden, 221-249. Amsterdam: Amsterdam University Press, 2017.

Van Zanden, Jan Luiten. “The Netherlands: The History of an Empty Box.” In European Industrial Policy: The Twentieth-Century Experience, edited by James Foreman-Peck and Giovanni Federico, 177-193. Oxford: Oxford University Press, 2006.

Warlouzet, Laurent. "The Rise of European Competition Policy, 1950-1991: A Cross-Disciplinary Survey of a Contested Policy Sphere.” EUI RSCAS Working Paper No. 80. Florence: European University Institute-Robert Schuman Centre of Advanced Studies, 2010.

- "Competition at the Service of the Market." In The History of the European Commission 1973-1986, edited by Michel Dumoulin, Élisabeth Palmero, Vincent Dujardin, Eric Bussière, Piers Ludlow, and Jan Willem Brouwer, 291-301. Luxembourg: Publications Office of the European Union, 2014.

—. "The Collapse of the French Shipyard of Dunkirk and EEC State-Aid Control.” Business History (2017), doi: 10.1080/00076791.2017.1307341.

Wilder, Matt. "What Is a Policy Paradigm? Overcoming Epistemological Hurdles in Cross-Disciplinary Conceptual Adaptation.” In Policy Paradigms in Theory and Practice: Discourses, Ideas and Anomalies in Public Policy Dynamics, edited by John Hogan and Michael Howlett, 19-43. London: Palgrave, 2015.

Wolf, Johanna. "Bremer Vulkan: A Case Study of the West German Shipbuilding Industry and Its Narratives in the Second Half of the Twentieth Century." In Shipbuilding and Ship Repair Workers Around the World: Case Studies 1950-2010, edited by R. Varela, H. Murphy, and M. van der Linden, 117-143. Amsterdam: Amsterdam University Press, 2017. 
Newspapers, Magazines, and Television Episodes

De Telegraaf (Amsterdam)

Groene Amsterdammer

NRC Handelsblad (Netherlands)

VPRO. Andere Tijden. Episode De RSV-Enquête. Nederland 2, February 19, 2012, 21:15, accessed December 19, 2019, https://anderetijden.nl/aflever ing/175/De-RSV-enquete.

\section{Legal Documents}

Judgment of the Court on September 17, 1980. Philip Morris Holland BV v Commission of the European Communities, Case 730/79. ECLI:EU:C:1980: 209.

Judgment of the Court 6 July 6, 1982. French Republic, Italian Republic and United Kingdom of Great Britain and Northern Ireland v Commission of the European Communities. Joined cases 188 to 190/80. ECLI:EU:C:1982:257.

\section{Primary Sources and Archives}

Archive of European Integration of the University of Pittsburgh (AEI), accessed December 19, 2019, http://aei.pitt.edu.

Handelingen en Kamerstukken van de Tweede Kamer der Stagengeneraal, accessed December 19, 2019, stagengeneraaldigitaal.nl.

Historical Archives of the European Union (HAEU), Oral History, accessed December 19, 2019, https://archives.eui.eu/en/oral_history.

National Archive, The Hague (NA), 2.08.107, Ministerie van Economische Zaken: Directoraat-Generaal voor de Buitenlandse Economische Betrekkingen.

Rijksmuseum, Foto-opdrachten Nederlandse geschiedenis: documentatie: Verkiezingsstrijd '81. Photos of Paul Babeliowsky, accessed December 19, 2019, www.geheugenvannederland.nl. 